\title{
Combined thickness of the uterus and placenta and ultrasonographic examinations of uteroplacental tissues in normal pregnancy, placentitis, and abnormal parturitions in heavy draft horses
}

\author{
Yuki KIMURA ${ }^{1,2}$, Shingo HANEDA ${ }^{1}$, Takahiro AOKI ${ }^{1,3}$, Hidefumi FURUOKA ${ }^{2,4}$, \\ Wataru MIKI ${ }^{2,5}$, Natsuko FUKUMOTO ${ }^{6}$, Motozumi MATSUI ${ }^{1,2}$ and Yasuo NAMBO ${ }^{1-3 *}$ \\ ${ }^{1}$ Division of Clinical Veterinary Medicine, Obihiro University of Agriculture and Veterinary Medicine, \\ Hokkaido 080-8555, Japan \\ ${ }^{2}$ United Graduate School of Veterinary Sciences, Gifu University, Gifu 501-1 193, Japan \\ ${ }^{3}$ Research Center for Global Agromedicine, Obihiro University of Agriculture and Veterinary, Hokkaido 080-8555, \\ Japan \\ ${ }^{4}$ Division of Veterinary Science, Obihiro University of Agriculture and Veterinary Medicine, Hokkaido 080-8555, \\ Japan \\ ${ }^{5}$ Federation of Hokkaido Agricultural Mutual Aid Associations, Hokkaido 069-0806, Japan \\ ${ }^{6}$ National Livestock Breeding Center, Hokkaido 080-0572, Japan
}

\begin{abstract}
The combined thickness of the uterus and placenta (CTUP) and ultrasonographic images of uteroplacental tissues were investigated in 35 pregnant heavy draft horses in Months 7-12 of pregnancy. The mares were divided into three groups: those pathologically diagnosed as placentitis (placentitis group, $n=3$ ); those who had abortion, premature birth, or fetal malformation (abnormal group, $n=7$ ); and those who had no abnormal findings (normal group, $n=25)$. In the normal group, CTUP increased as pregnancy progressed from Months 7 (median, $7.08 \mathrm{~mm}$; range, 5.68-11.27) to $12(13.31 \mathrm{~mm} ; 7.44-16.31 \mathrm{~mm})(P<0.05)$ and was higher than those reported previously in Thoroughbred, quarter, and American paint horses. Values of CTUP greater than the 75th percentile of the normal group from Months 7 $(7.54 \mathrm{~mm})$ to $12(15.19 \mathrm{~mm})$ were detected in $100 \%$ of the placentitis group (3/3) and in $86 \%$ of the abnormal group (6/7). Ultrasonographic images showing placental separation were obtained in $67 \%$ of the placentitis group (2/3), 29\% of the abnormal group (2/7), and 20\% of the normal group (5/25). Pathological placental edema and ultrasonographic images showing uteroplacental roughness or distinguishability were observed even in the normal group. These findings suggest that increased CTUP and placental separation would reflect placentitis and abnormal pregnancies and may help to detect them in heavy draft horses.
\end{abstract}

Key words: abnormal parturition, heavy draft horse, placentitis, ultrasonography

Japanese heavy draft horses are crossbreeds of Percheron, Belgian, and Breton draft horses. Their body weight can be

Received: June 2, 2017

Accepted: January 30, 2018

*Corresponding author. e-mail: ynambo@obihiro.ac.jp

C2018 Japanese Society of Equine Science

This is an open-access article distributed under the terms of the Creative Commons Attribution Non-Commercial No Derivatives (by-nc-nd) License. (CC-BY-NC-ND 4.0: https://creativecommons.org/licenses/ by-nc-nd/4.0/)
J. Equine Sci. Vol. 29, No. 1 pp. 1-8, 2018 over $1,000 \mathrm{~kg}$, making them one of the largest and heaviest types of horses worldwide [4, 7]. Some reproductive problems, such as retained placenta [6], dystocia [21], and acute metritis [18], are more frequently observed in heavy draft horses than in light horse breeds, although the reasons underlying these differences are unclear. In particular, the risk of retained placenta increases if a mare has placentitis peripartum [18]. Ascending placentitis, caused by bacteria and fungi from the vagina, is the main cause of pregnancy loss $[2,17]$. The presence of clinical signs, including vaginal 
discharge, premature udder development, and lactation before parturition, called running milk, indicates that placentitis has reached an advanced stage [19].

To diagnose ascending placentitis in light horse breeds, the combined thickness of the uterus and placenta (CTUP) is measured using transrectal ultrasonography. In ascending placentitis, CTUP increases $[9,11,14,20]$, and placental separation [14] and uteroplacental distinguishability [11, 14] are recognized. However, little is known about CTUP and ultrasonographic images of the uteroplacental tissues in heavy draft horses. We hypothesized that high CTUP values and images of abnormal uteroplacental tissues would be associated with not only ascending placentitis but also abnormal parturition. The purposes of this study were to determine normal CTUP values and evaluate ultrasound examination of CTUP and uteroplacental tissues in placentitis and abnormal parturition in heavy draft horses.

\section{Materials and Methods}

\section{Animals}

From 2013 to 2015, 35 pregnant heavy draft horses (7 Percherons, 1 Breton, and 27 Japanese heavy draft horses, which are a crossbreed of Percheron, Breton, and Belgian draft horses) at two private stud farms and the National Livestock Breeding Center in the Tokachi area of Hokkaido were studied. They were clinically healthy when the study was initiated. Mares at the two private farms were free to eat only a mixture of mostly timothy grass dry hay during this study. At the National Livestock Breeding Center, mares were free to eat a mixture of mostly timothy grass dry hay and were fed oats ( $2 \mathrm{~kg} / \mathrm{mare}$ ), a balanced diet (mainly comprising wheat bran, lucerne, and dry rolled corn; 0.5 $\mathrm{kg} / \mathrm{mare}$ ), calcium phosphate (50 g/mare), and supplements (vitamin A, 62,500 IU/mare; vitamin D, 12,500 IU/ mare; and vitamin E, 1,250 mg/mare) twice daily during this study. All mares included in this study could freely consume mineral salts. Mares were left outside except in the peripartum period and monitored at pen from about 1 week before parturition to a few days after. Their median age was 8 years (range, 3-19) and median parity was 2 (range, $0-13$ ). The study protocol was approved by Obihiro University of Agriculture and Veterinary Medicine, the Animal Care and Use Committee of the National Livestock Breeding Center, and the two private farms. The pregnancy diagnosis and relative sampling for this study were also permitted by the owners of all three farms.

\section{Ultrasonography}

From the seventh month of pregnancy, transrectal ultrasonographic examinations were performed using an HS-101V with an HLV-155 5-MHz liner transducer (Honda
Electronics Co., Ltd., Aichi, Japan). The mares were tested once per month from Months 7 to 12 of pregnancy. If mares could not be tested because of a farmer's schedule, the ultrasonographic data of those mares were excluded from that month of pregnancy. The value of CTUP was obtained by measuring the uterus and the placenta from the cranial and ventral aspects of the cervical pole $[12,15]$, and the mean value of three points was used. If there were differences in thickness between different parts of uteroplacental tissues, the thickest part was used. If images of uteroplacental roughness, placental separation, and distinguishability of the uterus and placenta, which means that a clear borderline could be seen between these tissues, were obtained, they were recorded. Months of pregnancy were defined according to a previous report [16]: Month 7 was 181-210 days, Month 8 was 211-240 days, Month 9 was 241-270 days, Month 10 was 271-300 days, Month 11 was 301-330 days, and Month 12 was 331-360 days.

\section{Examination of expelled placentas}

Expelled placentas were obtained from 30 of 35 parturitions. The other five placentas were not collected, either because expelled placentas could not be found or the farmers were not skilled in sampling. The region close to cervical star was cut [14], fixed with $10 \%$ buffered formalin, and embedded in paraffin for pathological examination. Sections were stained with hematoxylin-eosin to diagnose placentitis according to placental edema, necrosis, hemorrhages, inflammatory cells, and accumulation of fibrin [14]. Pathological placental edema was also recorded.

\section{Group design}

The horses were divided into three groups. Horses diagnosed with pathological placentitis were placed in the placentitis group $(n=3)$. Horses with abnormal parturition, which included abortion, premature birth, and gross malformation, and without diagnosis of placentitis were placed in the abnormal group $(n=7)$. Horses without pathological placental examination showed abnormal parturition, and they were included in the abnormal group. Abortion was defined as observed discharge of a conceptus late in pregnancy [3], and premature birth was defined as parturition within 320 days of pregnancy [10]. Horses that were clinically healthy and not diagnosed as having placentitis or abnormal parturition were placed in the normal group $(n=25)$.

\section{Statistical analysis}

Comparison of CTUP values between months in the normal group was performed by Scheffé's $F$ test following one-way analysis of variance. In the normal group, comparison of CTUP values between horses with and without 
Table 1. Background information of the placentitis and abnormal groups

\begin{tabular}{|c|c|c|c|c|c|c|c|c|c|c|}
\hline Mare & Group & Diagnosis & Farm & $\begin{array}{l}\text { Pathological } \\
\text { placental } \\
\text { examination }\end{array}$ & Placentitis & $\begin{array}{l}\text { Pathologi- } \\
\text { cal placental } \\
\text { edema }\end{array}$ & $\begin{array}{l}\text { Month-year } \\
\text { of foaling }\end{array}$ & $\begin{array}{l}\text { Month/day } \\
\text { of preg- } \\
\text { nancy }\end{array}$ & $\begin{array}{l}\text { Sex of } \\
\text { foals }\end{array}$ & Foal's prognosis \\
\hline A & Placentitis & Placentitis & $\mathrm{a}$ & Tested & Observed & Observed & Mar-15 & $11 / 309$ & $\mathrm{M}$ & Death \\
\hline B & Placentitis & Placentitis & $\mathrm{b}$ & Tested & Observed & Not observed & Mar-15 & $11 / 305$ & M & Death \\
\hline $\mathrm{C}$ & Placentitis & Placentitis & $\mathrm{a}$ & Tested & Observed & Not observed & Apr-15 & $12 / 334$ & Unknown & Death \\
\hline D & Abnormal & Abortion & $\mathrm{b}$ & Not tested & Not tested & Not tested & Jan-17 & $10 / 284$ & Unknown & Death \\
\hline $\mathrm{E}$ & Abnormal & Abortion & $\mathrm{b}$ & Tested & Not observed & Observed & Feb-17 & $11 / 315$ & Unknown & Death \\
\hline $\mathrm{F}$ & Abnormal & Prematurity & $\mathrm{c}$ & Not tested & Not tested & Not tested & Mar-17 & $11 / 315$ & M & $\begin{array}{l}\text { FPT, diarrhea, } \\
\text { arthritis }\end{array}$ \\
\hline G & Abnormal & Prematurity & $\mathrm{c}$ & Not tested & Not tested & Not tested & Mar-17 & $11 / 318$ & $\mathrm{~F}$ & Weak \\
\hline $\mathrm{H}$ & Abnormal & Prematurity & $\mathrm{c}$ & Not tested & Not tested & Not tested & Feb-16 & $11 / 319$ & M & Clinically healthy \\
\hline I & Abnormal & Malformation & $\mathrm{c}$ & Not tested & Not tested & Not tested & Feb-17 & $10 / 283$ & M & Death \\
\hline $\mathrm{J}$ & Abnormal & Malformation & $\mathrm{a}$ & Tested & Not observed & Not observed & Apr-17 & $12 / 348$ & M & Death \\
\hline
\end{tabular}

FPT, failure of passive transfer.

placental edema was performed by Mann-Whitney $U$ test in Month 7, Student's $t$-test in Months 8-11, and the Welch's $t$-test in Month 12, according to distribution and variance of dates in each month. Comparisons of incidence of mares that showed CTUP values of more than 10, 15, or $20 \mathrm{~mm}$ during examination and comparisons of the incidence of ultrasonographic images of uteroplacental tissue roughness, placental separation, and uteroplacental distinguishability between groups were performed by $X^{2}$ test for independence, followed by Fisher's exact test. In the normal group, the 25 th and 75 th percentiles and $95 \%$ confidence interval of CTUP values were calculated every month using Excel software (Microsoft, 2013). The incidence of CTUP values in the placentitis and abnormal groups that were more than the 75 th percentile of the normal group, the incidence of CTUP values that were more than 10,15 , or $20 \mathrm{~mm}$ in all groups, and the incidence of ultrasonographic images showing uteroplacental roughness, placental separation, and uteroplacental distinguishability in all groups were calculated by dividing the number of mares showing these CTUP values or images during the study by the number of mares included in each group. Differences with $P<0.05$ were considered statistically significant, and those with $P<0.1$ were considered to show a tendency. All statistical analyses were performed with Statcel3 (OMS Publishing Inc., Saitama, Japan).

\section{Results}

\section{Details of the placentitis and abnormal groups}

The background information of the placentitis and abnormal groups is shown in Table 1. Three horses were diagnosed with placentitis (Mares A-C). Of them, Mare A gave premature birth at 309 days of pregnancy, with her foal dying immediately after birth; Mare B aborted at 305 days of pregnancy; and Mare C underwent cesarean section and died along with her fetus at 334 days of pregnancy. Seven mares were in the abnormal group: Mares D and E aborted at 284 and 315 days of pregnancy, respectively; Mares F-H gave premature birth at 315,318 , and 319 days of pregnancy, respectively; and Mares I and J foaled malformed fetuses at 283 and 348 days of pregnancy, respectively. Expelled placentas from Mares E and J were pathologically examined and diagnosed as not showing placentitis, and placentas from the other five mares were not examined.

\section{CTUP}

Values of CTUP are shown in Fig. 1 and Table 2. In the normal group, CTUP values were significantly higher in Months 10 (median, $12.34 \mathrm{~mm}$; range, 9.61-20.11 mm), 11 (median, $13.19 \mathrm{~mm}$; range, 8.34-19.81 mm), and 12 (median, $13.31 \mathrm{~mm}$; range, $7.44-16.31 \mathrm{~mm}$ ) than those in Month 7 (median, $7.08 \mathrm{~mm}$, range, 5.68-11.27 mm; $P<0.01$ ) and were significantly higher in Months 11 and 12 than those in Month 8 (median, $8.35 \mathrm{~mm}$; range, 3.67-10.69 mm; $P<0.05)$.

Values of CTUP greater than the 75th percentile of the normal group were shown by all placentitis cases $(100 \%$ : Mare A in Month 11; Mare B in Months 8-10; and Mare $\mathrm{C}$ in Months 7, 8, and 11) (Fig. 2a) and six mares in the abnormal group (85.7\%: Mares D and E in Month 9; Mare $\mathrm{F}$ in Months 7, 10, and 11; Mare G in Month 10; Mare I in Month 8; and Mare J in Month 11) (Fig. 2b-d). One mare (Mare H) did not show these CTUP values (Fig. 2c). The incidence of CTUP values greater than $15 \mathrm{~mm}$ was $28.0 \%$ in the normal group (7/25: one mare showed this only in Month 10, two mares showed this only in Month 11, two mares showed this only in Month 12, one mare showed this in Months 9 and 12, and one mare showed this in Months 10 and 11$)$ and $100 \%$ in the placentitis group (3/3: Mare A 


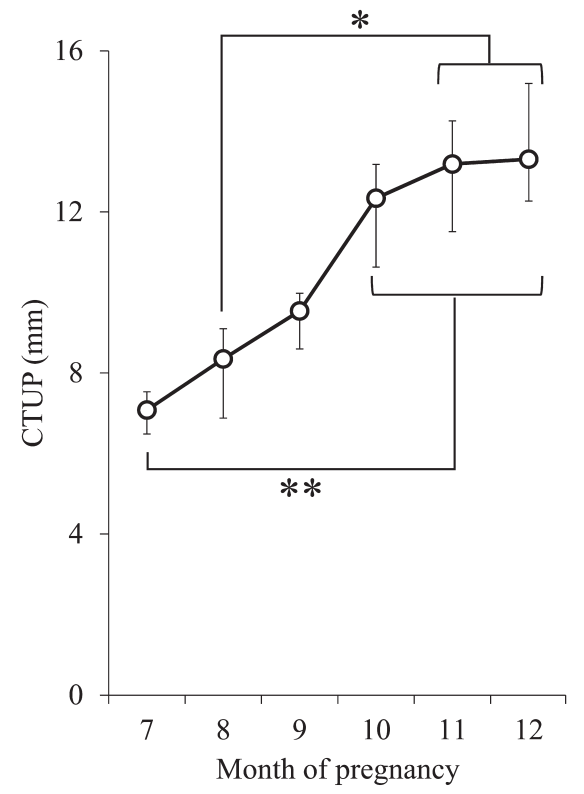

Fig. 1. Change in CTUP values in the normal group. Values of CTUP increased as pregnancy progressed. Data are shown as the median and 25th and 75th percentiles. Statistical significance is denoted by asterisks $(* P<0.05 ; * * P<0.01)$. CTUP, combined thickness of the uterus and placenta.

showed a CTUP value of $15.61 \mathrm{~mm}$ in Month 11; Mare B showed a CTUP value of $17.47 \mathrm{~mm}$ in Month 10; and Mare C showed a CTUP value of $16.30 \mathrm{~mm}$ in Month $7,16.21 \mathrm{~mm}$ in Month 8, and $17.14 \mathrm{~mm}$ in Month 11), and the incidence in the placentitis group was significantly higher than that in the normal group $(P<0.05)$. The incidence of CTUP values greater than $15 \mathrm{~mm}$ in the abnormal group was $42.9 \%(3 / 7$ : Mare F showed a CTUP value of $21.01 \mathrm{~mm}$ in Month 7 , $26.42 \mathrm{~mm}$ in Month 10, and $30.04 \mathrm{~mm}$ in Month 11; Mare G showed a CTUP value of $17.01 \mathrm{~mm}$ in Month 10; and Mare J showed a CTUP value of $19.24 \mathrm{~mm}$ in Month 11), and no statistically significant differences were observed between this group and the other two groups. There were also no statistical significant differences among the three groups in the incidence of CTUP values greater than 10 or $20 \mathrm{~mm}$.

Ultrasonographic images of uteroplacental roughness

Ultrasonographic images of uteroplacental roughness are shown in Figs. 3 and 4. Uteroplacental roughness was detected in almost all cases in all groups $(72.0 \%$ in the normal group and $100 \%$ in the placentitis group and the abnormal group, with no statistical difference).

\section{Ultrasonographic images of placental separation}

Placental separation was observed in two of the three mares in the placentitis group (66.7\%: Mare A in Month 11 and Mare B in Month 10) and two mares in the abnormal group (28.6\%: Mares F and H in Month 11) (Figs. 4 and 5). Mare F showed extensive placental separation at 314 days of pregnancy and gave premature birth the next day (Fig. 5). In the normal group, placental separation was detected in five mares $(20.0 \%)$; one mare showed placental separation in Months 11 and 12, two mares showed placental separation only in Month 11, and two mares showed placental separation only in Month 12. There were no statistical differences in incidences among the groups.

\section{Distinguishable uterus and placenta}

Uteroplacental distinguishability was observed in one of the three mares in the placentitis group (33.3\%: Mare C in Months 11 and 12) and three mares in the abnormal group (42.9\%: Mare E in Month 11, Mare F in Month 10, and Mare J in Month 11). In the normal group, uteroplacental distinguishability was detected in eight mares $(32.0 \%$ : one mare only in Month 7, two mares only in Month 11, four mares only in Month 12, and one mare in Months 10 and 11). There were no statistical differences in incidences among the groups.

\section{Pathological placental edema}

In the normal group, there were no differences between the CTUP values of horses with and without placental edema throughout pregnancy. The percentage of cases with pathological placental edema was $48.0 \%(12 / 25)$ in the normal group. Details of the placental examinations

Table 2. Values and change of combined thickness of the uterus and placenta (CTUP) in the normal group from Month 7 to Month 12 of pregnancy

\begin{tabular}{lcccccr}
\hline & $\begin{array}{c}\text { Month 7 } \\
(\mathrm{n}=11)\end{array}$ & $\begin{array}{c}\text { Month 8 } \\
(\mathrm{n}=5)\end{array}$ & $\begin{array}{c}\text { Month 9 } \\
(\mathrm{n}=5)\end{array}$ & $\begin{array}{c}\text { Month 10 } \\
(\mathrm{n}=10)\end{array}$ & $\begin{array}{c}\text { Month 11 } \\
(\mathrm{n}=21)\end{array}$ & $\begin{array}{c}\text { Month 12 } \\
(\mathrm{n}=11)\end{array}$ \\
\hline Median of CTUP (mm) & $7.08^{\mathrm{a}}$ & $8.35^{\mathrm{A}}$ & 9.54 & $12.34^{\mathrm{b}}$ & $13.19^{\mathrm{bB}}$ & $13.31^{\mathrm{bB}}$ \\
25th-75th percentiles (mm) & $6.49-7.54$ & $6.88-9.10$ & $8.60-9.98$ & $10.63-13.18$ & $11.51-14.26$ & $12.27-15.19$ \\
Range (mm) & $5.68-11.27$ & $3.67-10.69$ & $7.00-18.69$ & $9.61-20.11$ & $8.34-19.81$ & $7.44-16.31$ \\
$95 \%$ CI (mm) & $6.26-8.24$ & $4.44-11.04$ & $5.08-16.44$ & $10.57-15.22$ & $11.95-14.34$ & $11.29-14.98$ \\
\hline
\end{tabular}

Superscripts denote statistical significance (AB, $P<0.05$; ab, $P<0.01)$. CI, confidence interval. 

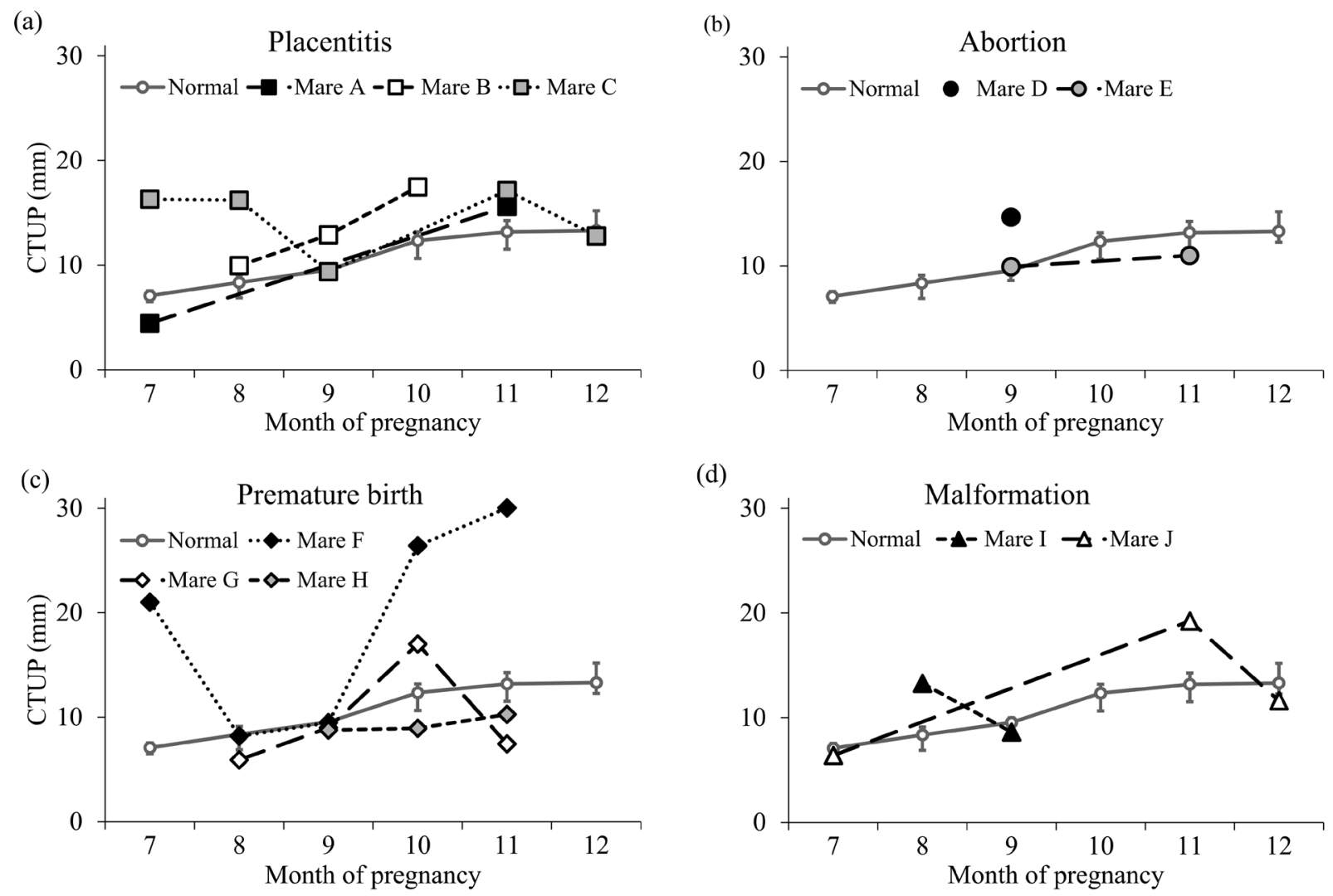

(d)

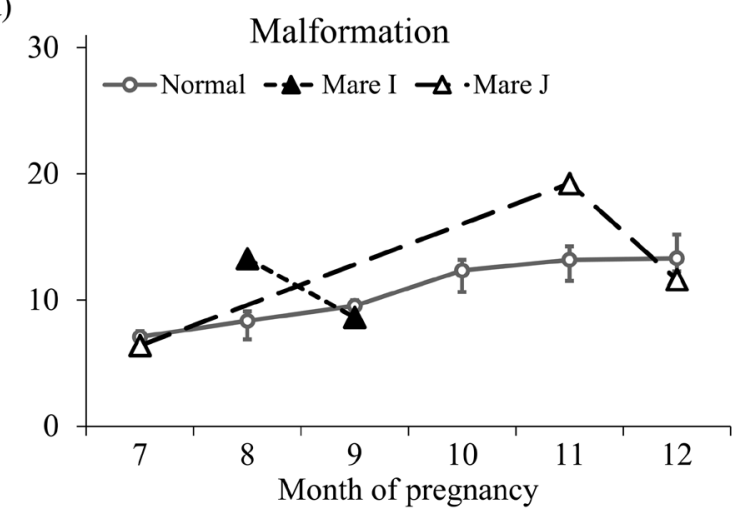

Fig. 2. Change in CTUP values in the normal group and cases of placentitis (a), abortion (b), premature birth (c), and malformation (d). Data of the normal group are shown as the median and 25th and 75th percentiles with $\bigcirc$ and a solid line. Data of cases of placentitis $(\bullet)$, abortion $(\bullet)$, premature birth $(\diamond)$, and malformation $(\boldsymbol{\Delta})$ are shown with dotted lines.

in the placentitis and abnormal groups are shown in Table 1. Regarding the placentitis group, Mare A was diagnosed with placental edema, and Mares B and $\mathrm{C}$ were not. We could not detect mares with pathological placental edema by ultrasonography. There was no relation between mares with pathological placental edema and those with ultrasonographic images of placental separation and/or uteroplacental distinguishability.

\section{Discussion}

This study is the first report on the CTUP of Japanese heavy draft horses. Values of CTUP in the normal group increased as pregnancy progressed, consistent with previous reports on light horse breeds $[8,12,15,16]$ and ponies [1, 11]. This result indicates that increased CTUP values during pregnancy may be an equine physiological change regardless of their breed. Values of CTUP in the normal group were higher than those reported in light horse breeds [8, $12,15,16,20]$ and ponies [1, 11]. Correlations have been reported between CTUP and placental weight [8]; therefore, high placental weight in heavy draft horses may explain the high CTUP values in this study.

In Thoroughbred, quarter, and American paint horses $[13,14,20]$ and ponies $[1,11]$ with placentitis, high CTUP values have been reported. In our study, all horses in the placentitis group (100\%) showed CTUP values greater than those observed in the 75th percentile of the normal group, and the upper $25 \%$ of the normal group were included in this range. Mares showing CTUP values greater than $15 \mathrm{~mm}$ were more frequent in the placentitis group (100\%) than in the normal group $(28.0 \%, P<0.05)$. The results indicated that in heavy draft horses, CTUP increased in the horses with placentitis and that measuring CTUP can be useful to detect placentitis. In our hypothesis, high CTUP values were speculated to be associated with imminent labor in addition to the placentitis, as placental edema was reported as one cause of still birth and abortion [5]. Some mares $(85.7 \%)$ in the abnormal group in this study showed CTUP values greater than those observed in the 75 th percentile of the normal group. Thus, CTUP values were likely to increase in cases of abnormal parturitions in heavy draft 
(a)

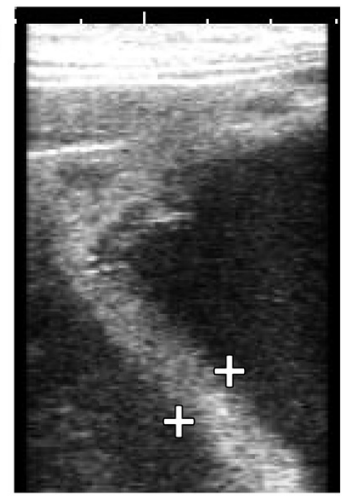

(c)

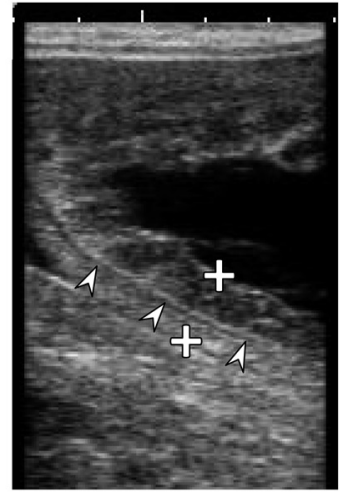

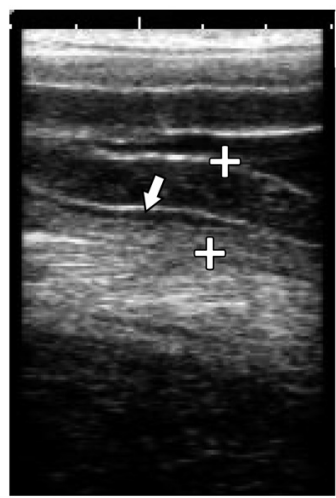

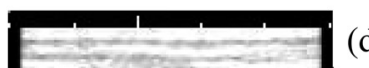

(b)

(d)

horses. However, only 2 placentas in the abnormal group were examined pathologically, and placental edema was not detected in one of the two cases. This may be explained by the fact that the area examined was a trimmed area of the placenta near the cervical reason, not the grossly abnormal region. Further investigation is necessary with more number of pathological placental examinations.

In our study, placental separation occurred in a higher percentage of in the placentitis group $(66.7 \%)$ than in the abnormal (28.6\%) and normal groups (20.0\%), although the differences were not statistically significant. Placental separation, however, would likely prevent placental function, and a previous report on placentitis in light horse breeds showed ultrasonographic images of placental separation [14]. It was suspected that the incidence of placental separation may increase in placentitis in heavy draft horses similar to that in light horse breeds, but placental separation was detected even in the normal group. Therefore, heavy draft horses may have little tolerance to placental separation. If placental separation is observed, other examinations, such as hormone measurements, will be need. Further investigations with more cases are necessary.

Distinguishability between the uterus and placenta was previously observed with placental development in Thoroughbreds [12]. In this study, there were no differences in the incidence of uteroplacental distinguishability between the normal $(32.0 \%)$, placentitis $(33.3 \%)$, and abnormal groups $(42.9 \%)$. Furthermore, images of uteroplacental distinguishability were recorded during late pregnancy

(a) Mare A

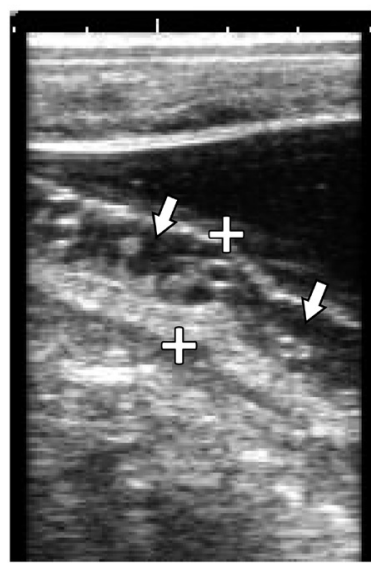

(b) Mare B

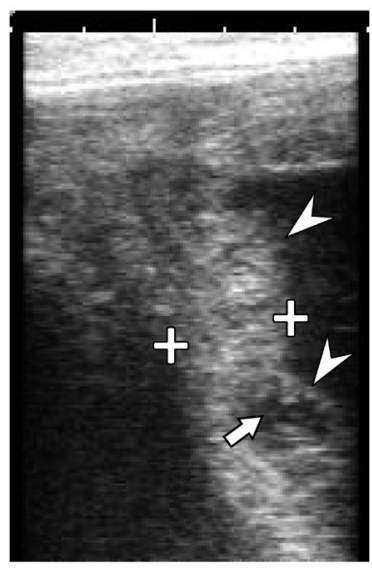

(c) Mare C

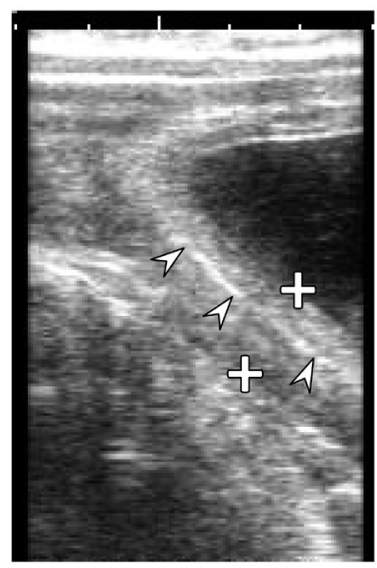

Fig. 4. Ultrasonographic images of horses diagnosed with placentitis. The distance of the CTUP is shown between + and +. Mare A: Image taken at 303 days of pregnancy. Six days later, she gave premature birth; the foal died immediately after birth. Placental separation can be recognized as the hypoechogenic area (arrow). Mare B: Image taken at 286 days of pregnancy; she aborted 19 days later. Roughness of uteroplacental tissues (large arrowheads) and placental separation (arrow) can be recognized. Mare C: Image taken at 333 days of pregnancy. Uteroplacental tissues are smooth; the uterus and placenta can be distinguished by a white line (small arrowheads). She underwent cesarean section the next day. 


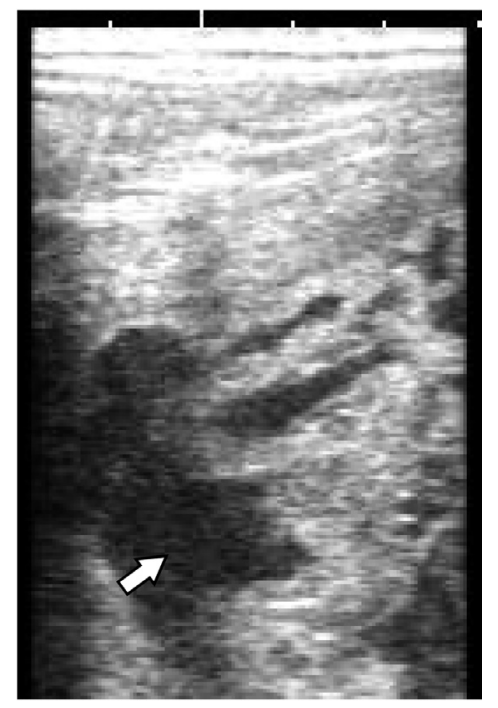

Fig. 5. Ultrasonographic images of Mare F. Extensive placental separation can be recognized as a large hypoechogenic area (arrow). This image was taken at 314 days of pregnancy, and this mare gave premature birth the next day.

after Month 10 except in one normal case. Therefore, it was considered that uteroplacental distinguishability indicated placental development in heavy draft horses and can be considered an equine physiological change.

Ultrasonographic images of roughness in uteroplacental tissues were commonly observed in all groups (incidence of $100 \%$ in the placentitis and abnormal groups and $72.0 \%$ in the normal group). On the other hand, they were reported in placentitis in light horse breeds [14]. Ultrasonographic tissue roughness can be common in heavy draft horses. The large size of the placenta may explain this phenomenon; for example, the large placenta became loose and folded near the cervix.

In some mares, CTUP decreased at some points. For example, in Mare C, CTUP in Month 9 was lower than that in Month 8. The exact reason for this was unclear, but the following things were considerable as reasons: measuring exactly the same area every time was too difficult, and the condition of tissue roughness changed. If abnormally high or low values and rapid increases or decreases in CTUP are detected, frequent examination and comprehensive observation including images of placental separation, hormone measurements, and the dam's clinical symptoms are recommended.

Regarding mares without pathological placental examination, Mares D, F, G, I, and J had CTUP values greater than those observed in the 75th percentile of the normal group; in particular, Mares F, G, and J had CTUP values greater than
$15 \mathrm{~mm}$. Mares $\mathrm{F}$ and $\mathrm{H}$ showed ultrasonographic findings of placental separation. Based on these findings, they may have had placentitis, but the details were unclear.

Pathological placental edema was detected in $48.0 \%$ of the mares in the normal group. In our hypothesis, CTUP would increase in the normal group if placental edema was present. However, there were no differences in CTUP values between horses with or without placental edema in the normal group. This possibly indicated that placental edema was too small to affect CTUP values or that placental conditions may have changed after parturition in a manner dependent on the placental retention time. In addition, placental edema is normal on the dorsal part of the placenta and has no clinical importance [16]; thus, the trimmed area may have been too near to the dorsal part. We could not find relationships between conditions of mares, ultrasonographic uteroplacental images, and results of pathological placental edema in the normal group. In addition, we did not discuss in detail the relationship between pathological placental edema, placentitis, and abnormal parturition due to the small number of pathological placental examinations. Furthermore, we could not exam all mares once per month continuously, even in the normal group. Further investigation with more animals subjected to pathological placental examination and continuous ultrasonographic examination is essential and may clarify whether or not a relationship between pathological placental edema, placentitis, and abnormal parturition exists.

In conclusion, our study clarified normal CTUP values in heavy draft horses. Values of CTUP in heavy draft horses were higher than those in Thoroughbred, quarter, and American paint horses reported previously, and they increased as pregnancy progressed. Although not statistically clear, in heavy draft horses, increased CTUP values and ultrasonographic images of placental separation may be useful to detect placentitis and abnormal parturition.

\section{Acknowledgments}

This work was supported by JSPS KAKENHI Grant Number 15K07735. We would like to thank all farmers and research associates for help with animal care and their excellent technical assistance.

\section{References}

1. Bailey, C.S., Heitzman, J.M., Buchanan, C.N., Bare, C.A., Sper, R.B., Borst, L.B., Macpherson, M., Archibald, K., and Whitacre, M. 2012. B-mode and Doppler ultrasonography in pony mares with experimentally induced ascending placentitis. Equine Vet. J. Suppl. 44: 88-94. [Medline] [CrossRef] 
2. Giles, R.C., Donahue, J.M., Hong, C.B., Tuttle, P.A., Petrites-Murphy, M.B., Poonacha, K.B., Roberts, A.W., Tramontin, R.R., Smith, B., and Swerczek, T.W. 1993. Causes of abortion, stillbirth, and perinatal death in horses: 3,527 cases (1986-1991). J. Am. Vet. Med. Assoc. 203: 1170-1175. [Medline]

3. Ginther, O.J. 1992. Reproductive efficiency. pp. 499-562. In: Reproductive Biology of the Mare, 2nd ed. (Ginther, O.J. ed.), Equiservices, Cross Plains.

4. Hiraga, A., and Sugano, S. 2017. Studies on the exercise physiology of draft horses performed in Japan during the 1950s and 1960s. J. Equine Sci. 28: 1-12. [Medline] [CrossRef]

5. Hong, C.B., Donahue, J.M., Giles, R.C. Jr., Petrites-Murphy, M.B., Poonacha, K.B., Roberts, A.W., Smith, B.J., Tramontin, R.R., Tuttle, P.A., and Swerczek, T.W. 1993. Equine abortion and stillbirth in central Kentucky during 1988 and 1989 foaling seasons. J. Vet. Diagn. Invest. 5: 560-566. [Medline] [CrossRef]

6. Ishii, M., Aoki, T., Yamakawa, K., Magata, F., Gojo, C., Ito, K., Kayano, M., and Nambo, Y. 2013. Relationship between the placental retention time and the reproductive performance at the foal heat in Thoroughbred and a comparison with Heavy Draft. J. Equine Sci. 24: 25-29. [Medline] [CrossRef]

7. Kashiwamura, F., Avgaandorj, A., and Furumura, K. 2001. Relationships among body size, conformation, and racing performance in banei draft racehorses. J. Equine Sci. 12: 1-7. [CrossRef]

8. Klewitz, J., Struebing, C., Rohn, K., Goergens, A., Martinsson, G., Orgies, F., Probst, J., Hollinshead, F., Bollwein, H., and Sieme, H. 2015. Effects of age, parity, and pregnancy abnormalities on foal birth weight and uterine blood flow in the mare. Theriogenology 83: 721-729. [Medline] [CrossRef]

9. LeBlanc, M.M. 2010. Ascending placentitis in the mare: an update. Reprod. Domest. Anim. 45:(Suppl 2): 28-34. [Medline] [CrossRef]

10. Lester, G.D. 2011. Prematurity, dysmaturity and assessment of maturity. pp. 121-127. In: Equine Reproduction, Vol. 1, 2nd ed. (McKinnon, A.O., Squires, E.L., Vaala, W.E., and Varner, D.D. ed.), Wiley-Blackwell, Oxford.

11. Morris, S., Kelleman, A.A., Stawicki, R.J., Hansen, P.J., Sheerin, P.C., Sheerin, B.R., Paccamonti, D.L., and LeB- lanc, M.M. 2007. Transrectal ultrasonography and plasma progestin profiles identifies feto-placental compromise in mares with experimentally induced placentitis. Theriogenology 67: 681-691. [Medline] [CrossRef]

12. Murase, H., Endo, Y., Tsuchiya, T., Kotoyori, Y., Shikichi, M., Ito, K., Sato, F., and Nambo, Y. 2014. Ultrasonographic evaluation of equine fetal growth throughout gestation in normal mares using a convex transducer. J. Vet. Med. Sci. 76: 947-953. [Medline] [CrossRef]

13. Murase, H., Niwa, H., Katayama, Y., Sato, F., Hada, T., and Nambo, Y. 2015. A clinical case of equine fungal placentitis with reference to hormone profiles and ultrasonography. J. Equine Sci. 26: 129-133. [Medline] [CrossRef]

14. Renaudin, C.D., Liu, I.K.M., Troedsson, M.H.T., and Schrenzel, M.D. 1999. Transrectal ultrasonographic diagnosis of ascending placentitis in the mare: a report of two cases. Equine Vet. Educ. 11: 69-74. [CrossRef]

15. Renaudin, C.D., Troedsson, M.H.T., and Gillis, C.L. 1999. Transrectal ultrasonographic evaluation of the normal equine placenta. Equine Vet. Educ. 11: 75-76. [CrossRef]

16. Renaudin, C.D., Troedsson, M.H.T., Gillis, C.L., King, V.L., and Bodena, A. 1997. Ultrasonographic evaluation of the equine placenta by transrectal and transabdominal approach in the normal pregnant mare. Theriogenology 47: 559-573. [Medline] [CrossRef]

17. Smith, K.C., Blunden, A.S., Whitwell, K.E., Dunn, K.A., and Wales, A.D. 2003. A survey of equine abortion, stillbirth and neonatal death in the UK from 1988 to 1997. Equine Vet. J. 35: 496-501. [Medline] [CrossRef]

18. Threlfall, W.R. 2011. Retained fetal membranes. pp. 2520-2529. In: Equine Reproduction, Vol. 2, 2nd ed. (McKinnon, A.O., Squires, E.L., Vaala, W.E., and Varner, D.D. ed.), Wiley-Blackwell, Oxford.

19. Troedsson, M.H. 2003. Placentitis. pp. 297-300. In: Current Therapy in Equine Medicine, 5th ed. (Robinson, N.D. ed.), W.B. Saunders, Philadelphia.

20. Troedsson, M.H., Renaudin, C.D., Zent, W.W., and Steiner, J.V. 1997. Transrectal ultrasonography of the placenta in normal mares and mares with pending abortion: a field study. Proceedings of the Annual Convention of the AAEP. 43: 256-258.

21. Vandeplassche, M. 1993. Dystocia. pp. 578-587. In: Equine Reproduction. (McKinnon, A.O., and Voss, J.L. ed.), Lea \& Febiger, Philadelphia. 